\title{
平押し法によるかえりなしせん断製品の寸法精度に関する研究
}

\section{Dimensional Accuracy on Burr Free Products by Push-Back Blanking}

\author{
○正 青木 勇（神奈川大） 正 笹田昌弘（神奈川大） \\ 内藤 侑貴 (神奈川大院) 松井亨 (侏東京システムズ)

\begin{abstract}
Ismu AOKI, Sasada MASAHIRO, Yuuki NAITO and Kanagawa University, 3-27-1 Rokkakubashi, Kanagawa-ku, Yokohama 221-8686, Japan Toru MATSUI Tokyo Systems Co.Ltd., 1-20-8 Ebisu, Sibuya-ku,Tokyo 150-0013, Japan
\end{abstract}

Key Words: burr-free blanking, push-back blanking dimensional accuracy

\section{1. 研究の背景と目的}

せん断加工で発生するかえり椂々な問題をもたらすため, 幾つかのかえりなしせん断法が提案されている. 牧野育雄氏 提案の平押し法 ${ }^{1)}$ はかえりなしの実現が容易な優れた工法で ある. 近年の機器の高度化に伴い, せん断製品にも高精度化 が求められており，平押し製品もこの例にもれない，平押し 法の成功条件等に関する報告 ${ }^{2)}$ はあるが，材料変形が複雑な ため寸法精度については詳細に検討されていない，本報では 平押し法の寸法精度についての実験と解析結果を報告する。

\section{2. 平押し法の加工原理}

平押し法は, 負クリアランスで半せん断する第 1 工程と, これを平板で押し戻し分離させる第 2 工程からなり，材料の 板両面にだれが形成され, かえりは生じない. 第 2 工程は仮 想せん断として解釈できる. 図 1(a)は半せん断材料の断面図で ある. 第 1 工程後の残留板厚を $\mathrm{t}$ とし, パンチ, ダイスに食い 込んだ材料部分をそれぞれ仮想ダイス，仮想パンチとすれば, 第 2 工程は, 同図(b)のように仮想工具による残留板厚 $\mathrm{t}$ のせ 儿断と考えられる. 第 2 工程を慣用せ九断之類似させるため には第 1 工程クリアランスは負でなければならない．

平押し製品は図 2 のように製品とかすの最大寸法が第 $1 工$ 程パンチ径（=仮想ダイス径）に，製品とかす最小寸法が第 1 工程ダイス径（=仮想パンチ径）に等しいはずであるが，実 際は僅かに異なる. 本報では, この誤差発生原因を検討する.

\section{3. 研究方法}

寸法誤差の発生原因を検討するため, 第 2 工程に着目し, 実験と有限要素解析により, 寸法精度に及ぼす半せん断製品 のだれとわん曲等の影響を以下のように調べることとした。

3.1 切削モデル試験片による実験

現象を単純化するため第 1 工程の半抜き製品を切削で作成 した. 試験片はアルミニウム押出し丸棒（JIS A1050BEH112,

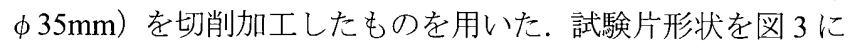
示す。それぞれ，(a)だれ・わん曲なし試験片，(b)だれあり試 験片, (c)わん曲あり試験片, (d)だれ・わん曲あり試験片と呼 ぶ.これらの試験片の食込み量（s） $2.1 \mathrm{~mm}$ (板厚比 $70 \%$ ), クリアランス $(\mathrm{cl}) 0.26 \mathrm{~mm}$ (板厚比- $8.7 \%$ )は一定とした. 図 3 中 のだれ，わん曲寸法は実駼值を元に決定した。 なお，製作の 都合上，パンチ・ダイス切刃に接する䇢所には $30 \mu \mathrm{m}$ の丸み を設けた．実験には平押し用ダイセットを使用し，加工力は ロードセルで, 工具変位はポテンショ変位計にて測定した。

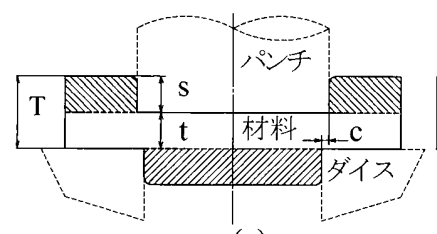

(a)

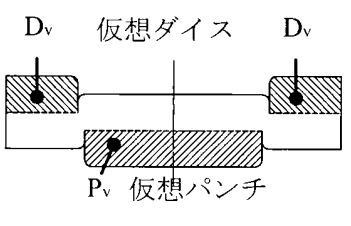

(b)
図 1 仮想せん断の模式図
加工速度は $0.1 \mathrm{~mm} / \mathrm{s}$ (無負荷時) で一定とした. 試験片直径 $\mathrm{D}_{0}$ は $30 \mathrm{~mm}$, 第 1 工程パンチ径 $\mathrm{D}_{\mathrm{p}}$ は $15 \mathrm{~mm}$, 板厚 $\mathrm{T}$ は $3 \mathrm{~mm}$ で一定とし, 第 1 工程ダイス径 $\mathrm{D}_{\mathrm{d}}$ 寸法と, 食い込み量 $\mathrm{s}$ 寸法 を変化させた. 平押し用ダイセットで試験片を押し戻し, 戻 し中, 及び分離後の製品とかす寸法（最大・最小）を計測す 万.

\section{2 解析方法と条件}

有限要素解析ソフトMarc2008r1 を用いて第 2 行程におけ る材料の変形と流動の解析を行う. 解析モデルは軸対称とし て扱い, 形状及び寸法は, 実験に合わせた。要素には四角形 四節点要素を用い, 材料特性は引張試験より求めた忘力一ひ ずタ曲線を用いた. 被加工材の塑性領域の特性を次式に示す.

$$
\bar{\sigma}=61.2+113.37 \bar{\varepsilon}_{p}{ }_{p}^{0.39}
$$

また, 弾性領域での材料特性は縦弾性係数 $69 \mathrm{GPa}$, ポアソ ン比 0.33 とした.

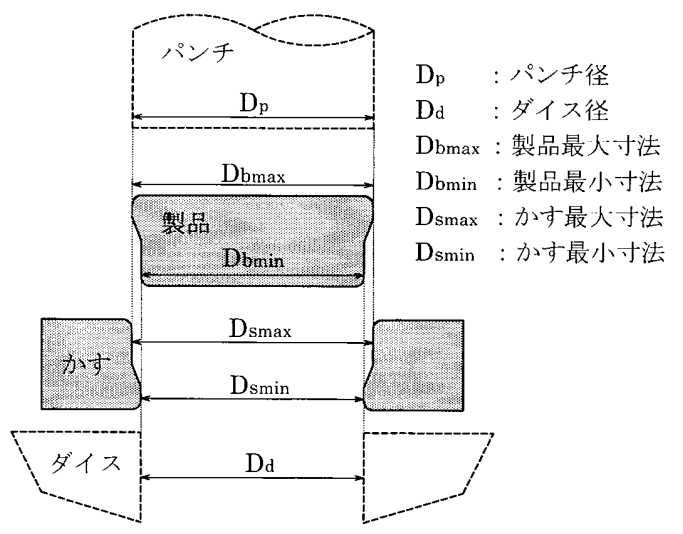

図 2 平押し製品，およびかす寸法と工具寸法の関係
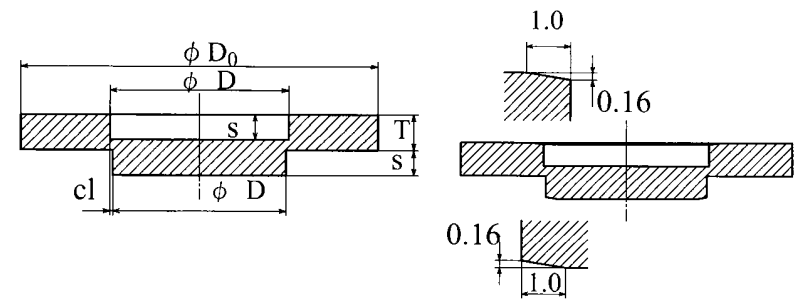

(a)だれ・わん曲なし試験片

(b)だれあり試験片
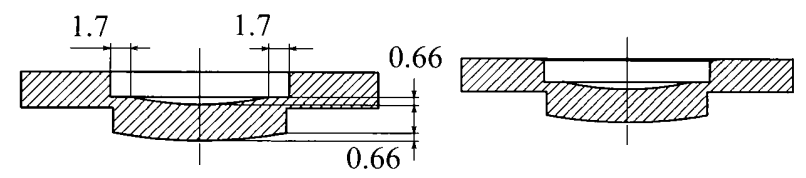

(c)わん曲あり試験片

(d)だれ・わん曲女り試験片

日本機械学会東海支部第 60期総会講演会講演論文集（'11.3. 14-15）No. 113-1 


\section{4. 結果及び考察}

4.1 誤差の発生機構

予備研究より平押し法の寸法誤差は製品側最小寸法，かす 側最大寸法が大きくなることがわかっている。図 4〜6 は実 験, 解析結果を試験片別に, 誤差 $\Delta 1 ， \triangle 2$ を表したもので ある。なお， $\Delta 1 ， \triangle 2$ は次式のとおりである.

$$
\begin{array}{ll}
\Delta 1=\mathrm{D}_{\mathrm{b} \min }-\mathrm{D}_{\mathrm{d}} & \text { (製品最小寸法-ダイス径) } \\
\triangle 2=\mathrm{D}_{\mathrm{smax}}-\mathrm{D}_{\mathrm{p}} & \text { (かす最大寸法-パンチ径) }
\end{array}
$$

また, 図 7 には試験片断面の変形状態を示す。これらより, （1）だれ・わん曲なし試験片：図 4 のとおり誤差は小さく, 図 7 (a)の断面からも理想的な仮想せん断々考えられる.

（2）だれあり試験片：図 5 のようにかす側最大寸法の誤差が 大きい．これは，だれによりクリアランス近傍の曲げモーメ ントが大きくなり，図 7(b)のように試験片かす側が跳ね上が り，か寸側最大寸法誤差を大きくしたためである.

（3）わん曲あり試験片：図 6 よりわん曲が製品側最小寸法に 影響する.わん曲を押し㞍す際に，図 7(c)のように製品側面部 が内向きに変形したためである.

(4) だれ・わん曲あり試験片：(2)，(3)が重畳した傾向となる.

以上のように，平押し法製品の寸法誤差はか子側最大寸法 と製品側最小寸法に大きく生じ，それぞれ第 1 工程で発生す るだれ，わん曲の影響であることがわかった。

4.2 切削モデル試験片とせん断試験片の比較

本来の第 1 工程はせん断である. 切削モデル試験片との比 較を図 8 に示寸. せん断試験片には傾斜面が生じこれが分離 後の製品とか寸の寸法精度, 形状精度に影響している. 傾斜 面は負クリアランスせん断であり，逆押さえの適用もあり， ダイス上材料が半径方向に大きく流動したためと考えられる.

\section{5. まとめ}

切削モデル試験片の実験・解析より得られた結果をまとめ ると, (1)だれ・わん曲なし試験片の場合, 寸法誤差はほとん どなく, 第 2 工程も理想的変形となる. (2)かす側最大寸法の 誤差は, 第 1 工程で形成されるだれの影響によるものであり, 理想的な寸法より大きくなる。(3)製品側最小寸法の誤差は, 第 1 工程で形成されるわん曲の影響によるものであり, 理想 的な寸法より小さくなる.

また，せん断試験片の場合，第 1 工程で生じる形状不良が 製品形状に影響する。

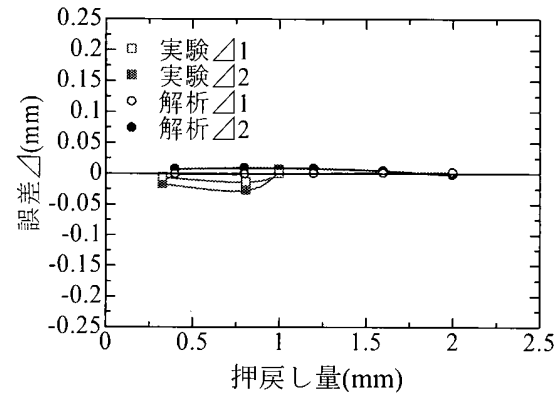

図 4 だれ・わん曲なし試験片の寸法誤差

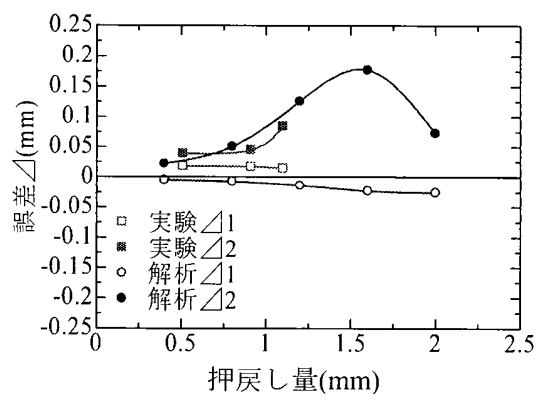

図 5 だれあり試験片の寸法誤差
謝辞 本研究の一部は文部科学省科学研究費補助金 (研究番号 22560121）の支援によるものであり，記して梁甚の謝意を表す。

\section{参考文献}

(1)牧野育雄：プレス技術，25-13(1987), pp.73-78.

(2)青木勇・前田禎三 : かえりなしせん断加工機構に関する実 験的検討, 日本塑性加工学会誌, 32-364(1991-5), pp.621-626.

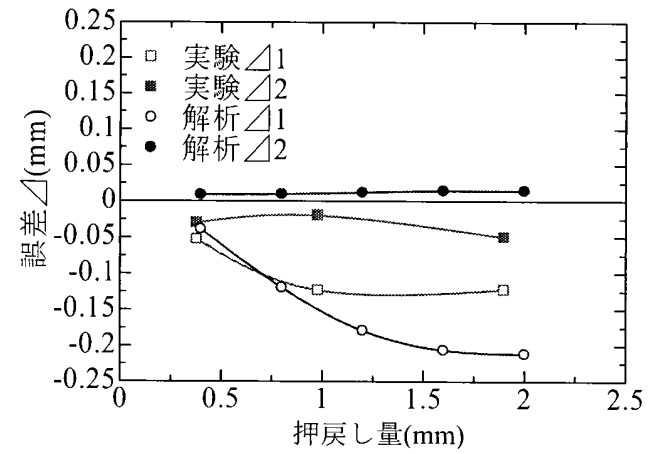

図 6 わん曲あり試験片の寸法誤差

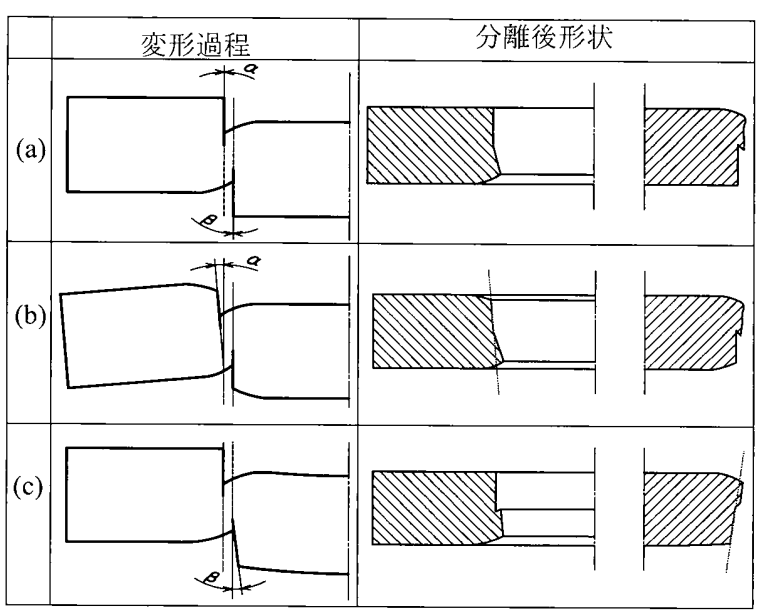

図 7 第 2 工程における材料変形 （(a)だれ・わん曲なし，(b)だれあり，(c)わん曲あり) (a) $\mathrm{x}=0 \%$

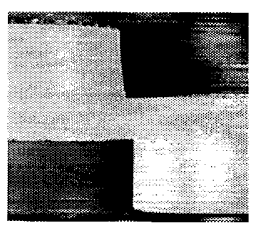

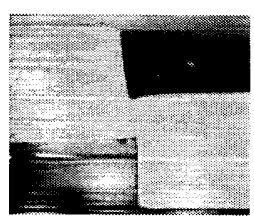

(b) $\mathrm{x}=13 \%$

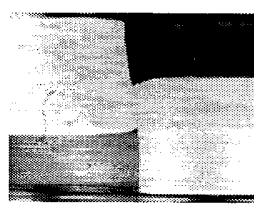

(c) $\mathrm{x}=45 \%$

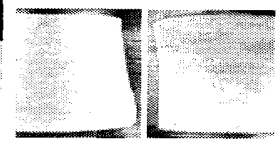

（d) 分離後製品
(1)第一工程はせん断（逆押さえ有り）

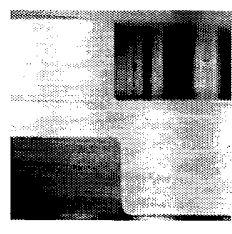

(a) $x=0 \%$

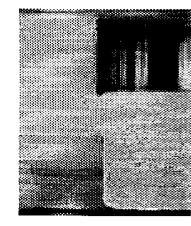

(b) $x=18 \%$

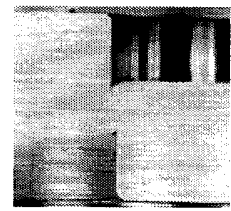

(c) $x=45 \%$

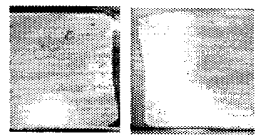

(d) 分離後製品
(2)第一工程は切削（だれ状傾斜あり，角丸み有り）

図 8 せん断試験片と切削モデル試験片の平押し時の変 形比較（(x: 残留板厚に対する押し戻し量 $(\%))$ 